IFAS Extension

\title{
Rosemary Grasshopper Schistocerca ceratiola Hubell and Walker ${ }^{1}$
}

John L. Capinera ${ }^{2}$

\section{Introduction}

There are six species of grasshoppers in the genus Schistocerca found in Florida. One species, the rosemary grasshopper, S. ceratiola Hubbell and Walker, occurs only in Florida and is poorly known and rarely seen except by those specifically seeking it out. Following is an illustrated summary of its appearance and ecology.

\section{Distribution}

The rosemary grasshopper is known only from central and northcentral Florida. It occurs in sand scrub areas from Clay County in the north of Florida to Highlands and Martin Counties in the south, and from the Atlantic Coast to the Gulf Coast of Florida. County records where S. ceratiola has been found include: Alachua, Clay, Hernando, Highlands, Lake, Levy, Martin, Orange, Polk, Putnam, Seminole and Volusia. Thus, the distribution of the grasshopper is more limited than that of its host plant, which extends along the coastal plain from southeastern South Carolina to southern Mississippi as well as peninsular Florida. Within this area, the host plant occurs only in xeric areas with deep sandy soils. Rosemary is easily killed by fire, and though locally abundant because it quickly colonizes disturbed soils after fires, eventually is will disappear as trees grow and shade the plants.

\section{Description}

Adults: Adult S. ceratiola are mottled gray and brown, with some pale green coloration on the abdomen. A pale tan stripe occurs on the upper surface of the head and pronotum, extending weakly along the forewings. On the head and pronotum, the pale stripe is bordered by thinner

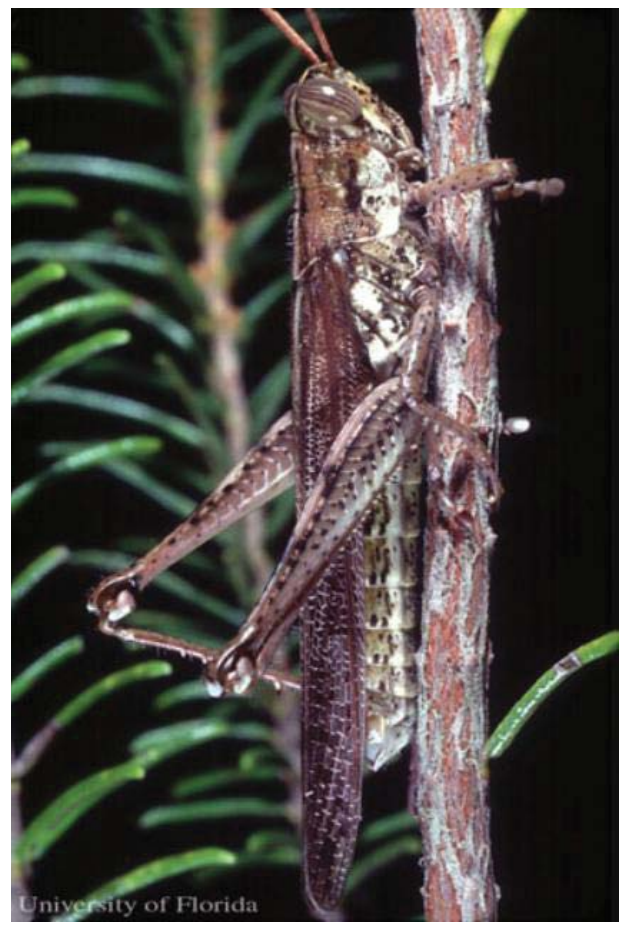

Figure 1. Adult male rosemary grasshopper, Schistocerca ceratiola Hubbell and Walker.

Credits: John L. Capinera, University of Florida

1. This document is EENY-496 (IN894), one of a series of Featured Creatures from the Entomology and Nematology Department, Florida Cooperative Extension Service, Institute of Food and Agricultural Sciences, University of Florida. Published: July 2011. This document is also available on Featured Creatures website at http://entomology.ifas.ufl.edu/creatures. Please visit the EDIS website at http://edis.ifas.ufl.edu.

2. John L. Capinera, professor/chairman, Entomology and Nematology Department, Cooperative Extension Service, Institute of Food and Agricultural Sciences, University of Florida, Gainesville, FL 32611. 
dark stripes. The underside of the grasshopper is markedly paler, mostly gray. The hind tibiae are red or brown. This species is quite slim in general appearance, slimmer and smaller than any other North American Schistocerca. The forewings are narrow, tapering to a rounded point, and extend well beyond the tip of the abdomen. The hindwings are transparent, although the veins are dark. The large eyes bear dark brown bands. Males are 28 to $32 \mathrm{~mm}$ long, females 36 to $40 \mathrm{~mm}$.

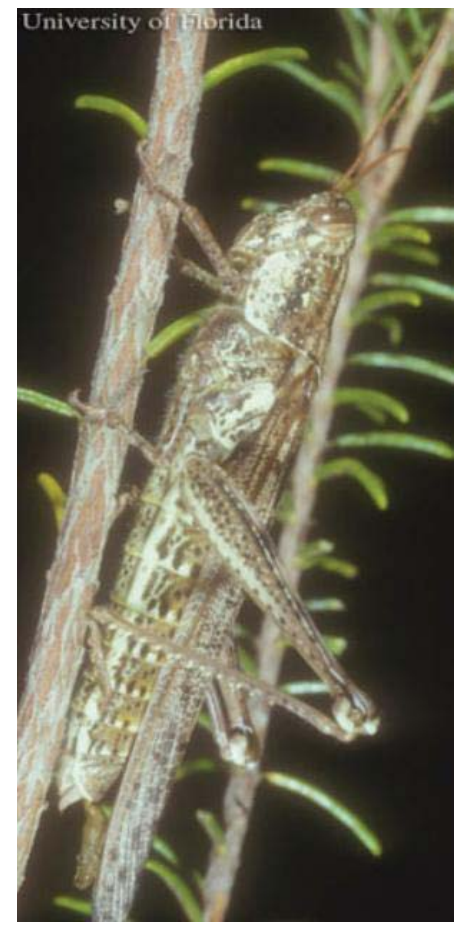

Figure 2. Adult female rosemary grasshopper, Schistocerca ceratiola Hubbell and Walker.

Credits: John L. Capinera, University of Florida

Nymphs: The appearance of nymphs contrasts strongly with the dull coloration of adults. Nymphs are bright yellowish green with a pair of yellow stripes located dorsolaterally and running the length of the body. Yellow patches are located elsewhere, especially on the upper surface of the hind femora. There are five nymphal instars that grow in size and display more advanced wing development with each molt. The number of eye bands increases as the nymph matures, though this character is not entirely reliable for determining the instar.

\section{Ecology}

Despite its moderately large size, the rosemary grasshopper is not often seen and is poorly known. It escapes detection due to its restricted range - it occurs only on Florida's sandy ridges; its restricted diet - it feeds only on Florida rosemary (Ceratiola ericoides); and its restricted period of activity - it is active only early in the evening. Normally it hides deep within rosemary bushes, where it is effectively camouflaged

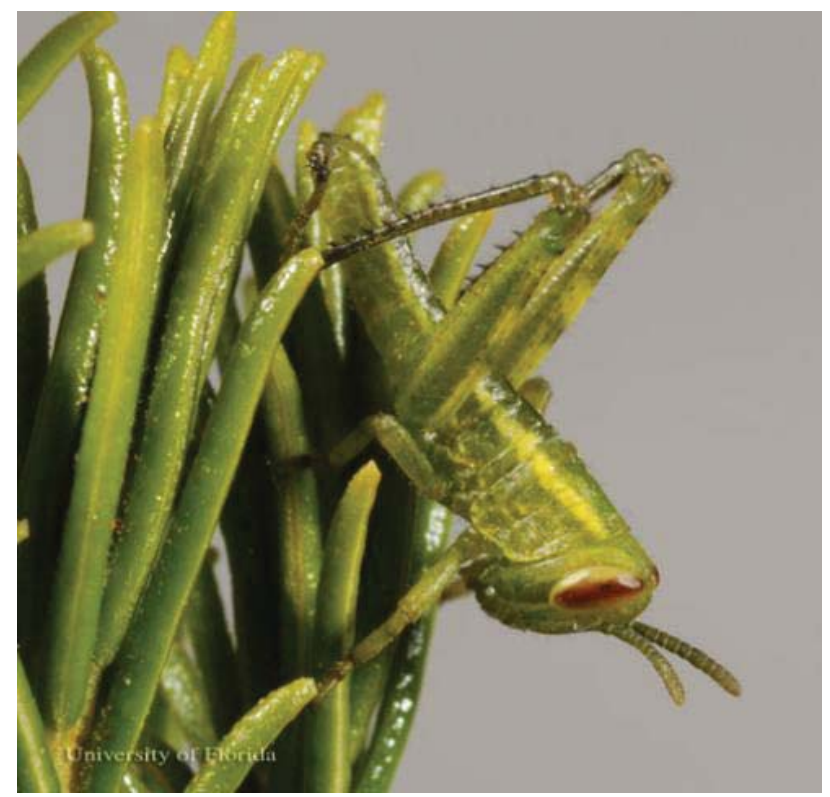

Figure 3. First instar nymph of the rosemary grasshopper, Schistocerca ceratiola Hubbell and Walker. Credits: Lyle J. Buss, University of Florida

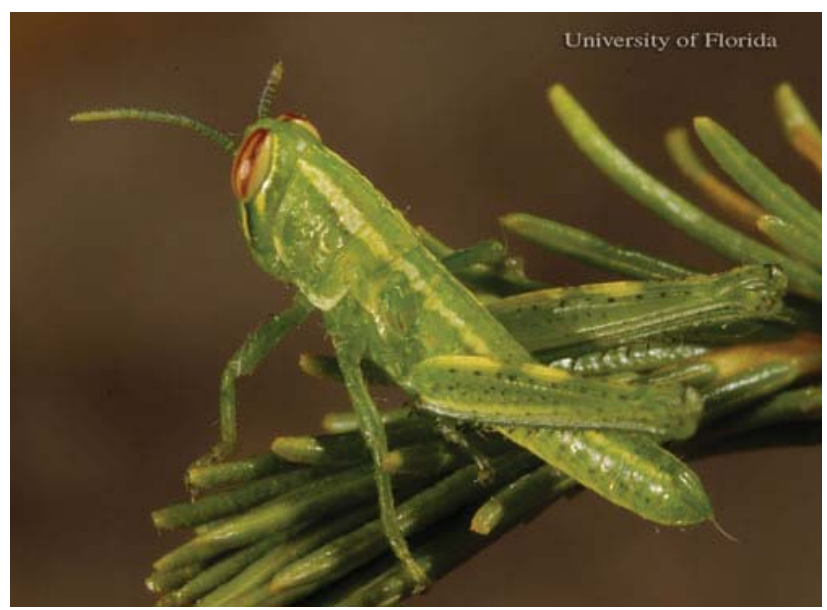

Figure 4. Second instar nymph of the rosemary grasshopper, Schistocerca ceratiola Hubbell and Walker. Credits: Lyle J. Buss, University of Florida

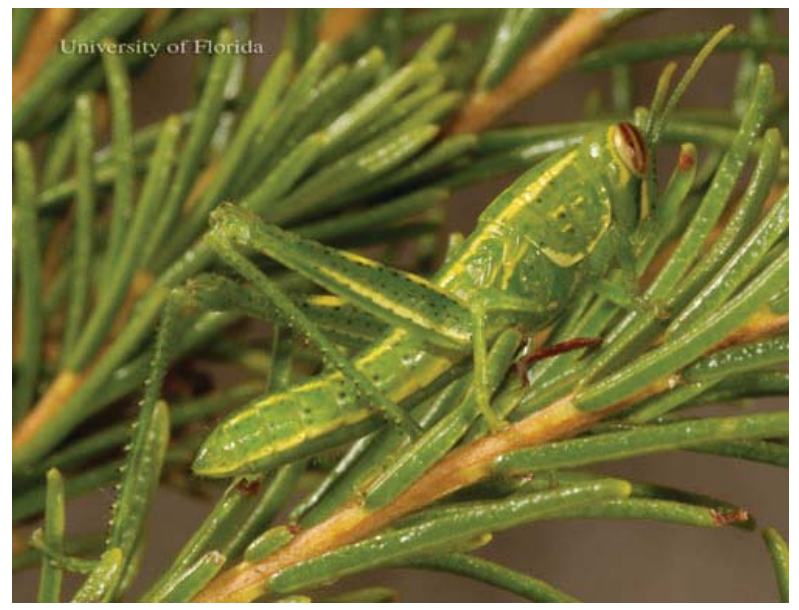

Figure 5. Third instar nymph of the rosemary grasshopper, Schistocerca ceratiola Hubbell and Walker. Credits: Lyle J. Buss, University of Florida 


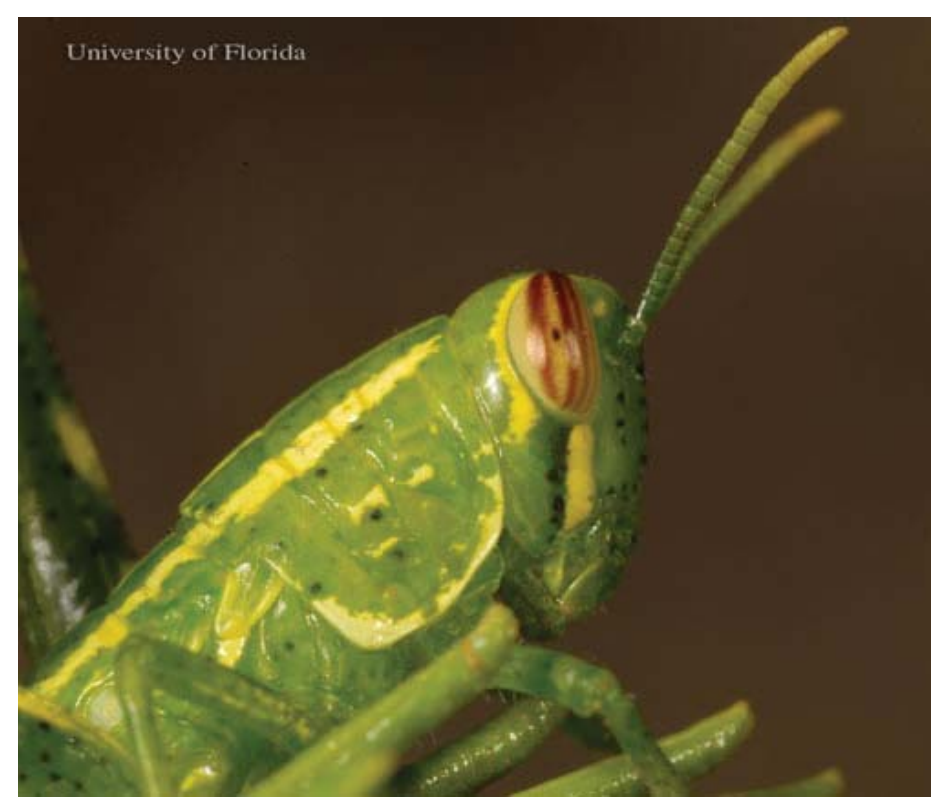

Figure 6. Close up of a third instar nymph of the rosemary grasshopper, Schistocerca ceratiola Hubbell and Walker.

Credits: Lyle J. Buss, University of Florida

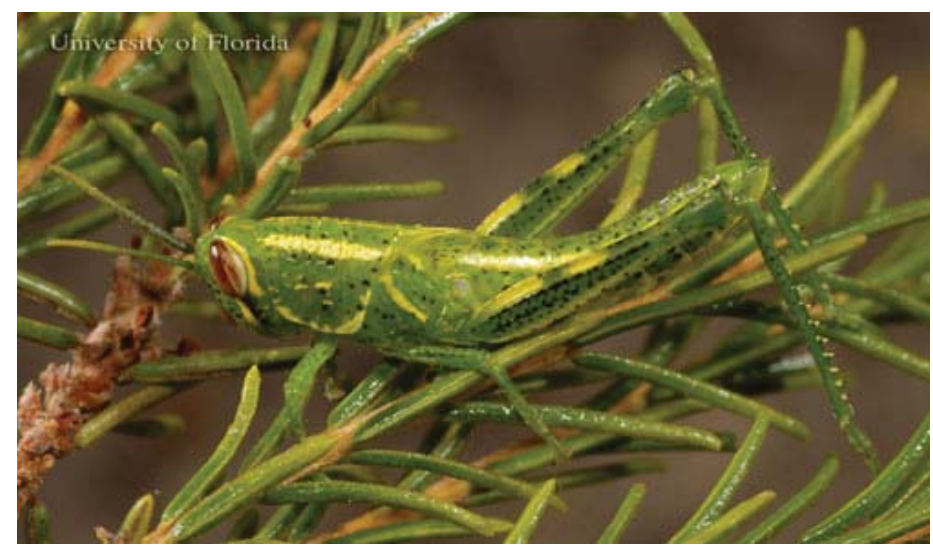

Figure 7. Fourth instar nymph of the rosemary grasshopper, Schistocerca ceratiola Hubbell and Walker. Credits: Lyle J. Buss, University of Florida

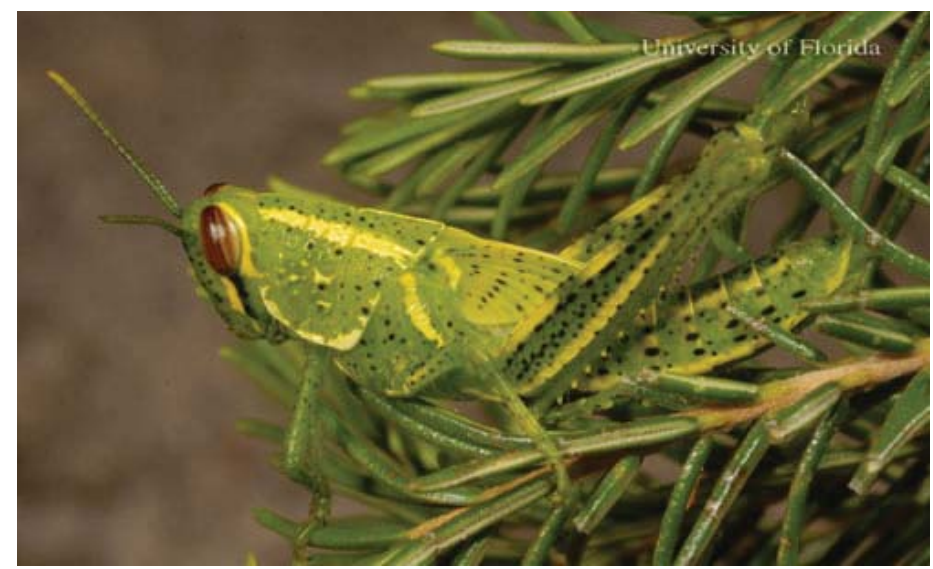

Figure 8. Fifth instar nymph of the rosemary grasshopper, Schistocerca ceratiola Hubbell and Walker.

Credits: Lyle J. Buss, University of Florida

during the daylight hours, moving to the surface of the bushes at night (or sometimes during periods of heavy cloud cover) where it feeds and copulates. The adults closely resemble the stems of rosemary, but the green and yellow nymphs blend perfectly with the foliage. The degree of host specificity displayed by the rosemary grasshopper, wherein a single plant species serves as the host plant, is extremely unusual in grasshoppers.

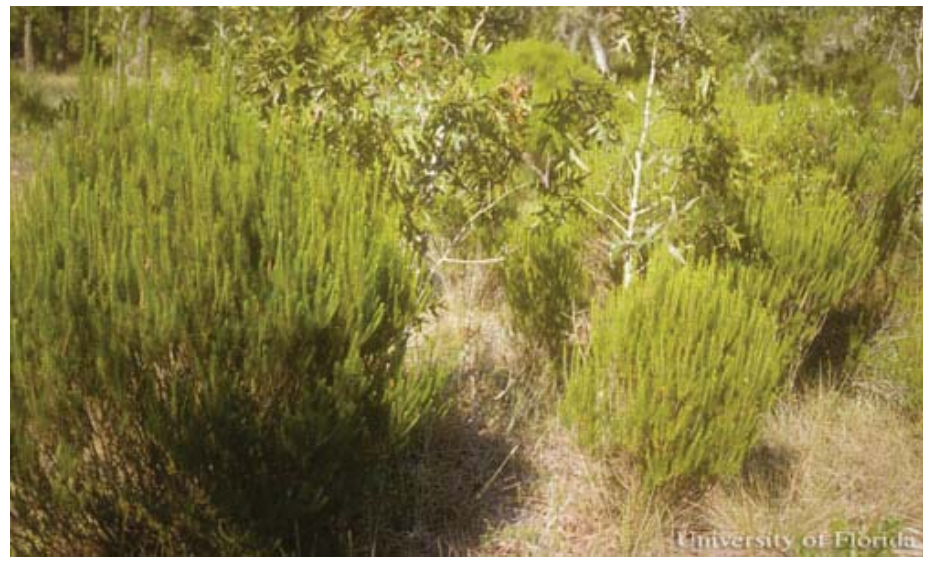

Figure 9. Florida rosemary, Ceratiola ericoides, shown growing in a sandhill habitat along with turkey oak, Quercus laevis. A large rosemary bush is shown at the left front of the image, and smaller rosemary bushes are on the right front. These bushes typically are rounded, and attain a height of 2 to 3 meters (7 to 10 feet). Florida rosemary is the host for the rosemary grasshopper, Schistocerca ceratiola Hubbell and Walker.

Credits: John L. Capinera, University of Florida

Adult grasshoppers are found in late summer to autumn. They are reluctant to fly, and when sufficiently disturbed as to take flight, they normally fly only short distances and directly to another rosemary bush.

Unlike many grasshoppers, this species causes no economic injury, and is interesting mostly due to its monophagous feeding behavior, restricted distribution, and cryptic appearance. Its habitat, the xeric sand ridges of Florida, is home to many unique animals and plants. The unusual flora and fauna likely are due to their long periods of geographic isolation, first by higher sea levels in past times that caused the sand ridges to become islands, and now by the differing flora that separates the intermittent hilly regions.

\section{Selected References}

- Capinera JL, Scott RD, Walker TJ. 2004. Field guide to grasshoppers, katydids, and cricket of the United States. Cornell University Press, Ithaca. 249 pp.

- Franz R, Franz SE. 1989. Records for the rosemary grasshopper, Schistocerca ceratiola Hubbell and Walker, in North America (Orthoptera: Acrididae). Florida Entomologist 72: 386-387. 
- Hubbell TH, Walker FW. 1928. A new shrub-inhabiting species of Schistocerca from central Florida. Occasional papers of the museum of zoology, University of Michigan 197. $10 \mathrm{pp}$.

- Johnson AF. 1982. Some demographic characteristics of the Florida rosemary, Ceratiola ericoides Michx. American Midland Naturalist 108: 170-174.

- Smith TR, Capinera JL. 2005. Host preferences and habitat associations of some Florida grasshoppers
(Orthoptera: Acrididae). Environmental Entomology 34: 210-224.

- Smith RT, Froeba JG, Capinera JL. 2004. Key to the grasshoppers (Orthoptera: Acrididae) of Florida. Florida Entomologist 87: 537-550.

- Squitier JM. 2000. A new record for Schistocerca ceratiola (Orthoptera: Acrididae). Florida Scientist 63: 104-107. 